\title{
Configuration of power relations in physicians and nurses' professional practices
}

\author{
Configuração das relações de poder nas práticas profissionais de médicos e enfermeiros \\ Configuración de las relaciones de poder en las prácticas profesionales de médicos y enfermeros
}

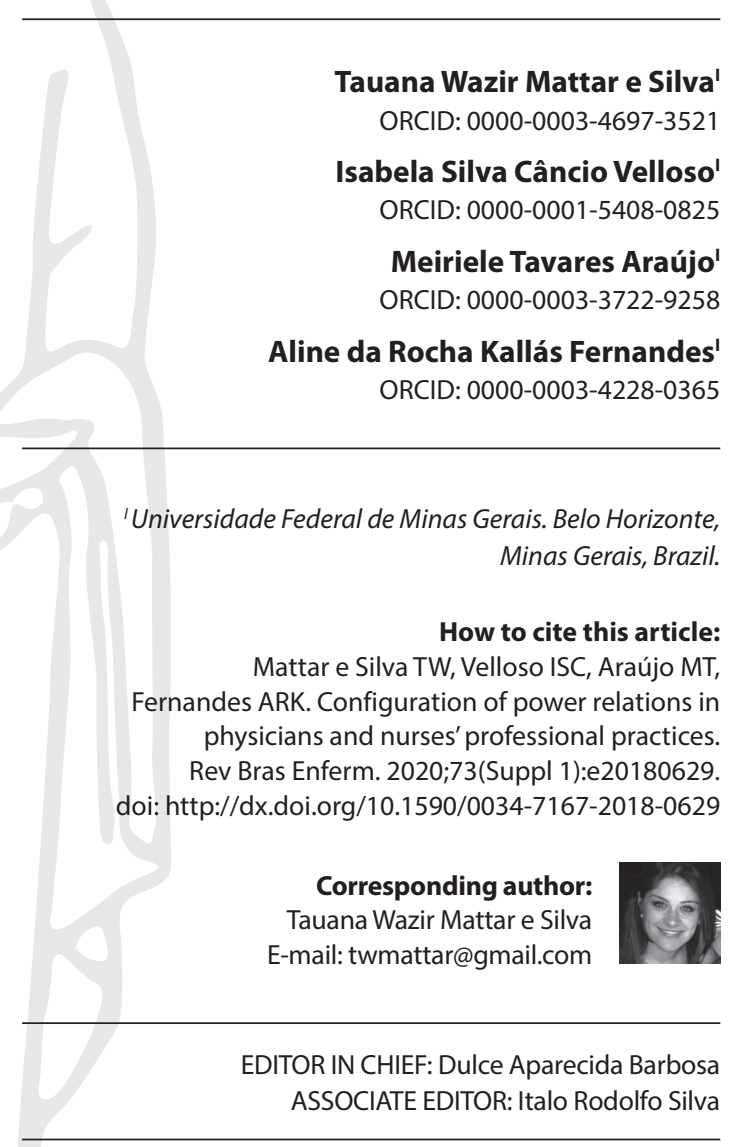

Submission: $08-07-2018$

Approval: 10-12-2019

\begin{abstract}
Objective: to analyze the configuration of power relations constituted in and by the knowledge and daily practices of physicians and nurses in an Intensive Care Unit (ICU). Method: qualitative study in which data were collected through interviews with physicians and nurses from an ICU of a hospital in Belo Horizonte, Minas Gerais. A semi-structured script was used. Data were analyzed through discourse analysis in a Foucaultian perspective. Results: three categories were developed - Professional Identity: self-recognition in the profession; Discipline: individualizing attitudes or collective need?; and Circularity of knowledge and power in the constitution of daily practices. Final considerations: the identity, discipline and circulation of power are connected in a continuous movement of subjectivation of the subject, which, in turn, uses discourse as a persuasion strategy to modify the position taken over in different situations thereby causing the circulation of power. Descriptors: Physician-Nurse Relations; Hospitals; Power (Psychology); Professional Practice; Health Knowledge, Attitudes, Practice.
\end{abstract}

\section{RESUMO}

Objetivo: analisar a configuração das relações de poder constituídas nos e pelos saberes e práticas cotidianas de médicos e enfermeiros em um Centro de Terapia Intensiva. Método: pesquisa qualitativa, com dados coletados por meio de entrevistas com roteiro semiestruturado com médicos e enfermeiros de um Centro Terapia Intensiva de um hospital de Belo Horizonte, Minas Gerais. Para a análise dos dados, foi utilizada a análise de discurso na perspectiva Foucaultiana. Resultados: foram elaboradas três categorias - Identidade profissional: o reconhecimento de si na profissão; Disciplina: atitudes individualizantes ou necessidade coletiva?; e Circularidade do conhecimento e do poder na constituição das práticas cotidianas. Considerações finais: a identidade, a disciplina e circulação do poder se conectam em um movimento contínuo de subjetivação do sujeito que, por sua vez, utiliza-se do discurso como estratégia de persuasão para modificar a posição assumida em diferentes situações, fazendo com que o poder circule.

Descritores: Relações Médico-Enfermeiro; Hospitais; Poder (Psicologia); Prática Profissional; Conhecimentos, Atitudes e Prática em Saúde.

\section{RESUMEN}

Objetivo: analizar la configuración de las relaciones de poder constituidas en y por el conocimiento y las prácticas cotidianas de médicos y enfermeros en una Unidad de Cuidados Intensivos. Método: investigación cualitativa con datos recopilados a través de entrevistas con guiones semiestructurados con médicos y enfermeros de una Unidad de Cuidados Intensivos de un hospital en Belo Horizonte, Minas Gerais. Para analizar los datos, se utilizó el análisis del discurso desde la perspectiva de Foucault. Resultados: se elaboraron tres categorías - Identidad profesional: auto reconocimiento en la profesión; Disciplina: ¿actitudes individualizadoras o necesidad colectiva?; y Circularidad de conocimiento y poder en la constitución de las prácticas cotidianas. Consideraciones finales: la identidad, la disciplina y la circulación del poder se conectan en un movimiento continuo de subjetivación del sujeto, que, a su vez, utiliza el discurso como estrategia de persuasión para modificar la posición asumida en diferentes situaciones, lo que provoca la circulación de poder.

Descriptores: Relaciones Médico-Enfermero; Hospitales; Poder (Psicología); Práctica Profesional; Conocimientos, Actitudes y Práctica en Salud. 


\section{INTRODUCTION}

The hierarchical structure of the health care model with relationships of order and levels of importance often generates a misunderstanding of the proposed archetype, because it overestimates the practices that require higher technological density developed at the tertiary level(1). The hospital, as a reference of care at the tertiary level, is also a symbol of the social power of the medical profession and favors the visibility of physicians as central actors of care practices ${ }^{(2)}$.

Until the eighteenth century, medicine was not a hospital practice, just as the hospital was not a medical institution, but rather a place intended essentially for the care of poor people ${ }^{(3)}$. Over time, it has become an environment for the cure of disease, and the doctor has taken over a central role in its organization ${ }^{(4)}$. Nowadays, even in the face of a scenario where the medicalcentered model is strongly appreciated, various components of the multidisciplinary team have increasingly expanded their scope of action ${ }^{(5)}$, which can generate tensions both between professionals in the same category and among the various categories.

With the focus on quality of care, hospital management has undergone a paradigm shift. There is a growing administrative professionalization of hospitals that requires the engagement of its professionals, including physicians, in bureaucratic activities mediated by nurses. In daily hospital work, nursing practices are generally focused on document management, and medical practices are more focused on patients' propaedeutics and therapeutics with limited ties to institutional norms ${ }^{(4)}$. However, nurses' position in the hospital context has been changing and these professionals are gaining more and more visibility given their involvement in care management ${ }^{(6)}$.

This conformation leads to a reconfiguration of practices and professional relationships established between physicians and nurses and, consequently, to the reconfiguration of power relationships constituted. Hence the need to understand the relationships established in this context, as they interfere with the work dynamics and the quality of care practices. It is important to consider that the power arising from knowledge circulates constantly and reconfigures the relationships according to the composition of forces constituted from knowledge and practices put into play ${ }^{(3,5)}$.

According to Foucault, the hospital can be an environment that changes the view of power ${ }^{(3)}$. The command exercised inside the hospital is not conceived as a property, but as a strategy with domination effects contributing to develop a network of tense relations in which the power exercised is often greater than the power possessed ${ }^{(3)}$. Thus, an Intensive Care Unit (ICU) is a privileged place for the analysis of power relations. In this environment, there is interaction of various types of professional knowledge, and medical practice is recognized and valued for triggering the entire process of reestablishing health to the critically ill biological body $y^{(7)}$.

The opposition to medical reductionism can lead to tensions among team professionals and consequent reconfiguration of power relations and health practices established between doctors and nurses ${ }^{(8)}$. Analyzing the configuration of these practices from the perspective of power relations is an attempt to explore care conventions as socially constituted elements and consider that such behaviors are structured from relationships and interactions that sustain and contradict themselves in multiple and complex structures ${ }^{(9)}$.

As power is constituted in the relationships and practices experienced daily in professional relationships, those with greater knowledge assume a privileged position in power relations ${ }^{(3)}$. By assuming that the circulation of power affects physicians and nurses' daily practices in the hospital setting and that the effects of this relationship may interfere with the quality of health service production, studies are needed to explore this thematic.

\section{OBJECTIVE}

To analyze the configuration of power relations constituted in and by the knowledge and daily practices of physicians and nurses in the hospital setting.

\section{METHOD}

\section{Ethical aspects}

The study complied with Resolution number 466/2012 and Resolution number 510/2016 of the National Health Council. The project was approved by the Ethics Committees of the UFMG and the hospital chosen as the study scenario. All participants read and signed two copies of the Informed Consent form.

\section{Type of study}

A qualitative study was developed from a poststructuralist perspective and analysis of participants' discourses, based on Michael Foucault's theoretical-methodological framework.

\section{Methodological procedures}

\section{Scenario and study participants}

The study was conducted at the adult Intensive Care Unit (ICU) of a large general philanthropic hospital in Belo Horizonte, Minas Gerais, Brazil. At the time of data collection, the ICU had 30 beds and a care team consisting of 17 nurses and 100 nursing technicians, a medical staff with 31 intensive care practitioners and five residents, totaling an average of 170 admissions/month.

Eight physicians and 12 nurses participated in the study. Inclusion criteria comprised all professionals formally integrating the ICU care team for a minimum period of four months, regardless of the type of contract. Professionals in the probationary period were excluded.

Saturation criterion, which is not supported by strictly numerical parameters, was used for sample definition. Within this criterion, there is no a priori delimitation of the number of participants, and the sample is interrupted when the collection of new data no longer arouses new theoretical insights and does not reveal new properties of the established categories ${ }^{(10)}$. The sample included as many individuals as necessary to better understand the reality studied. 


\section{Data collection and organization}

Data were collected from August to October 2017 through field observation and interviews with a semi-structured script using the following guiding questions directed to nurses: Talk a little about what is it like to be a nurse; What do you consider to be a good physician? The script of physicians had the following questions: Talk a little about what it is like to be a physician; What do you consider to be a good nurse? The common questions for both professionals were: How are the relations between physicians and nurses in daily work in the ICU? Do you believe the interaction established between physicians and nurses in the unit enables the best possible patient care? Why?; If you could improve anything in the physician-nurse relationship, what would you improve?

The sequence of interviews was randomly defined. The content was recorded on a media player device and transcribed in full to ensure the completeness and reliability of information.

The observed data were documented in a field diary. To ensure the anonymity of participants, they were identified by the initial capital letter corresponding to their professional category (physician - $\mathrm{P}$ and nurse - N) followed by the sequential number of the interview.

\section{Data analysis}

Discourse Analysis enables the understanding of the mode of operation, the principles of organization and forms of social production of meaning. In this analysis, the meaning of reports was described through objects, types of utterance, concepts, themes and theories ${ }^{(11)}$.

In the analysis of discourses, the social condition of their production, their ideological context (s) and the scenario and characters involved were considered thus, no generalizations can be made. It was observed how these characters merge and how relationships are established, and the persuasion strategies developed by the authors in the practice of their discourse. In data treatment, the characters, the lexical concept, and the nature of the vocabulary were identified. Furthermore, ideas put and presupposed by the said and the unsaid were selected, allowing the knowledge of elements silenced by participants and strongly connected in the discourses ${ }^{(11)}$. Data operationalization involved the steps of ordering and classification of data and final analysis ${ }^{(10)}$.

\section{RESULTS}

From data analysis, three categories were constituted: Professional identity: self-recognition in the profession; Discipline: individualizing attitudes or collective need?; and Circularity of knowledge and power in the constitution of daily practices.

\section{Professional identity: self-recognition in the profession}

The triggering question related to identity was: talk a little about what it is like to be a nurse/physician. At first, we observed amazement, long pauses and silence in nurses'statements, which demonstrated their difficulty of talking about themselves and their profession:

[silence for ten seconds] ... Well ... being a nurse is... (N4)
Yeah ... This must be the hardest question. (N3)

[silence for eight seconds] ... [...] It's hard to find a single answer. [...]. (N1).

The prolonged silence in the speeches suggests embarrassment in self-elaboration. Physicians, on the other hand, organized their responses with greater ease and naturality:

For me, being a physician is acting in patient care, [...]. (P1)

So ... trying to improve what is harming the patient or people is not [...] necessarily healing but an attempt to alleviate their suffering. [...] (P4)

\section{[...] it basically consists of taking care of people. (P8)}

In addition to the security of presenting opinions on the meaning of medicine, in most discourses, physician mentioned care as the identity of the profession. The following excerpt shows the love for the profession in a full-bodied speech of accomplishment and pride in having become a physician.

... Look, physician, for me, it's practically my identity. [...] it's my favorite thing to do in life, [...] an accomplishment too, isn't it?! [...] / love being a physician. (P5)

When the interviewee considers being a physician as his identity, he illustrates that this professional identity pervades his personal life, merges with it and leads to a blurring distinction between what is the subject and his work ${ }^{(12)}$. Although the professionalization and constitution of nursing identity is based on care ${ }^{(13)}$, some of nurses' discourses show the distance from direct patient care as the focus of their professional practice.

[...] before, I was more tied to procedures themselves, and nowadays, I feel much more important, [...] in the very organization and management of the service, [...] I guess that, you know, my role as a nurse is much more, [...] in this process organization than with the procedures. (N7)

In an opposite direction to the nature of nurses' work, these professionals are understanding care as a demerit, and seek in administrative activities, the affirmation of their importance in the work environment. The difficulty of some nurses with the definition of their professional identity expands the possibility of not being recognized and valued by other professionals and society and becoming invisible.

When asked about what would improve the physician-nurse relationship, a nurse answered:

I would improve this issue with a higher appreciation of nurses' work by physicians [...], understanding more the importance of our role [...] and by stopping to analyze more the things we say [...] by involving the team more, even in bedside rounds, in case discussions [...]. (N3)

The nurse does not seem to have his or her role defined nor a well-elaborated professional identity. In this professional 
personality conflict, the anguish of nurses is visible when they are excluded from decisions that concern care, although some refuse to assume this care as the essence of their own practice.

[...] How am I supposed to supervise? Because it's kind of our job as a nurse to inspect if there was a correct disinfection of the puncture site, if he [physician] washed his hands, if they wore sterile clothing and such, if gloves/how will I know that? And I'm charged for it. Sure! This is my role ... right [...]. (N2)

We perceive a subversion of the meaning of nursing care in which surveillance is a way to ensure adequate patient care. The presence of nurses in the sector requires initiative and knowledge, as reported by the following physician:

[a good professional] is the agile nurse, able to perceive pathological changes of the patient, who can understand what is serious, what is not serious, and who is not afraid to talk to the physician [...]. (P4)

The discourse of physicians demonstrates the desire for the presence of more committed nurses to direct patient care. This discourse assumes that nurses have little mastery over patients' clinical conditions and poor knowledge for the assessment of emergency situations.

[...] most nurses, they back out, they don't ...[...] face it, they don't really argue, right, it's [...] they think they're right or disagree with something, [...], many nurses think that the physician is a hierarchical level, you know, above us. And it's nothing like that! But nowadays, unfortunately, I guess it's for lack of knowledge, really. (N7)

In this discourse, it becomes clear that the lack of knowledge does not favor attitudes of coping and positioning and leads some nurses to remain in low visibility positions as a form of protection against exposures that may cause embarrassment.

\section{Discipline: individualizing attitudes or collective need?}

The subject, while a body part in a space, makes it possible to train such a body and make it useful through discipline ${ }^{(14)}$. In the exercise of health, it is noteworthy that the control is limited to physicians, who determine what should be done, while nurses' role is limited to the act of executing ${ }^{(15)}$ :

[...] If I do not have a good relationship [with the physician], how will I assist my patient? Because I depend on him for many things. [...] so I depend on approaching him and talking to ask for a prescription [...], I need him to make a request for an interdisciplinary consultation [...]. (N8)

There is a clear concern of this nurse with maintaining a harmonious relationship with the medical team for better patient care, which further nourishes the idea of medical supremacy.

[...] maybe this would be more.../ this issue of the physician having to understand more the bureaucracy of the sector in order to ... understand more the work of nurses too, when we demand some things from them/sometimes you have to request the simple use of a mask, [...] they look at you and say - No, I won't do it, I won't put the mask on, it's... they should understand it's not me/that I'm not asking it for myself, we ask for our patients, really. (N3)

For some professionals, nurses' role is to monitor the work of physicians, which, in some situations, generates resistance to the established discipline and conflict. The clinical and political interest of the contemporary world in activities that guarantee quality and patient safety is to optimize care and reduce the chance of care errors ${ }^{(16)}$. Patients may be exposed to a higher risk during an invasive procedure if safety standards are not adequate and if the nurse is unwilling to confront the medical staff to ensure them, as suggested in discourses of the physician and nurse below:

[...] the patient, poor thing, has to be lucky to have a nurse who has the courage to talk to the physician, and the physician is receptive, so he'll receive such care or conduct. So, I think this is a clear demonstration that relationships do interfere in the care provided. (N7)

I think in general, nurses respect the rules more than physicians [...], they comply more. (P2)

Nurses tend to assume primarily the duty to ensure that medical procedures are in accordance with institutional norms. This leads to the question of the nature of this bond, of the (in) existing trust relationship and perhaps of nurses' dependence on the physician for their performance:

I consider as a good physician, the professional who is able to listen, knows how to approach the team, tells the team of his work proposals, [...] how he will conduct the shift, [...]/guide the team towards what he wants, what are the conducts he will perform, [...]. Do you know what I mean? (N1)

We note nurses' desire that physicians share their knowledge. The fact that the main knowledge is delegated to physicians, as well as the responsibility to guide the care and progress of the shift, presupposes voluntary submission to medical supremacy.

The discourse of nurse N4 demonstrates adherence to norms and rules is not an option, but a duty for keeping the job.

[...] the nursing staff, in general, they respect more ... the norms. They are more careful with routine compliance than the physician. Because [...] we have a/we're required to have responsibility in a different way. (N4)

The fragment 'are required to have responsibility in a different way' shows the distinction of hierarchical and disciplinary conduct between physicians and nurses.

This study also pointed to the lack of communication between physicians and nurses as the main reason for the work without coordination and alignment between these two professional categories. In a certain way, this can bring care losses to patients.

I guess there is a communication problem, especially when sometimes we change some conduct and do not inform or forget to inform the Nursing staff and vice versa, [...]. (P1)

Communication failures between professionals of different categories disrupt teamwork. However, as most invasive procedures 
are routine and natural in the intensive care setting, physicians no longer realize their importance and the need to share such procedures with the rest of the team ${ }^{(17)}$.

The possibility of surveillance motivates the isolated work of physicians from the time that nurses can be inspectors of their actions. This fact presupposes physicians' refusal to submit to the power granted to nurses.

[...] even if you notify, so this doctor will be warned later, or someone calls the attention, [...]. (N7)

The physician is liable to mistakes, and the more people help to make less mistakes, the better! It's... and I think nurses are by our side just as technicians and the whole team are by our side in order that this happens. (P4)

At first, P4's discourse reinforces the greatness of teamwork and, on the other hand, the physician understands nurses' presence as an important factor to prevent them from making mistakes and succeeding in their own practice.

\section{Circularity of knowledge and power in the constitution of daily practices}

By complementing the etymology of the word knowledge through Foucault's philosophical lenses, the term defines what we can speak of with domain and property in a discursive practice ${ }^{(8)}$. The more disguised the power is, the stronger it will be, and a considerable way to diminish this power is by knowledge ${ }^{(18,}$ ${ }^{19)}$. Therefore, it is a dialectical relationship between power and knowledge in the subject's search for the truth.

[...] it's sometimes they [physicians] make a point, from their perspective, right, it's and I respect, right! Sometimes I even question something, but you know, as he is the most responsible for the treatment. [...] So, he puts it in a good way, explains politely, [...], by judgment, it's the correct procedure. So, I respect, it's, and there have been situations where I saw that it was not correct and in fact it was not [...]. (E5)

This discourse illustrates a dispute of knowledge in which physician and nurse position themselves according to their knowledge. However, the nurse still explicitly recognizes the medical supremacy in health practices. Thus, the level of visibility of the medical team can be understood as relatively proportional to their level of responsibility.

Although power relations are of force and confrontation, they are always reversible hence, there is no power relation completely triumphant and unavoidable ${ }^{(19)}$. As forces move, power circulates. The relationship between power and knowledge is the combination that gives or not visibility to the individual ${ }^{(20-21)}$. For Foucault, knowledge is not something intrinsic to men, but something invented, produced ${ }^{(22)}$.

[...] what is more stressful for us [nurses], in this matter of the physician-nurse relationship, is really this issue... that they should hear more, call our presence more [...] really have higher trust in the nurse. I guess sometimes they don't trust much. Maybe because of the pressure, right, of being a physician, right?! [...] the issue of decision making, which is often with the physician, isn't it?! [...]. (N12)

The excerpt portrays the passivity of this nurse in the professional relationship and his desire that the physician trusts him. But his discourse does not show strategies for changing the scenario. The nurse himself gave the physician a sovereignty sustained by the recognition of the burden of decision-making pressure. Nurses' visibility in the scenario of this study is connected to the mastery of norms, routines and standards.

It is ..., [...] who generally helps with this part [norms], are the nurses, who seem to be more organized in this regard, have more meetings. So, we depend on them [...]. (P4)

This physician points out that the nurse is the one who points the direction, contributes to the medical team performance according to the institution recommendations. In the sense of the word, the auxiliary verb announces, albeit silently, a supporting subject, subordinate, lower, assistant, helper ${ }^{(23)}$.

Yeah... [laughs] ... the nurse always has to be asking physicians to follow the rules, you know?! They don't care much about it [...] sometimes you see the physician doing something that you know is not right, you must impose yourself, you have to say it, - No, hang on, this thing you're doing is not right. That's it, that's it ... you must impose yourself, I think. (N3)

The discourse shows a tangible circulation of power through the domain of the norm when nurses have a firm attitude regarding their role in this situation and exercise their authority at the time of care procedures. On this occasion and considering this scenario, an analogy would be of the physician as the conductor of treatment and the nurse as the conductor of processes.

A mutual collaboration is expected in favor of better care for the critically ill patient, which benefits the constant circularity of power, as put by this nurse in his speech:

[...] it's... sometimes in the bedside round itself, really, it's... they [physicians] are discussing some case of a patient, and there's some information going unnoticed by the physician, and then you go and say, "Look, it's not that. This happened in such a day, it was in such a day that it happened". Then, you realize when they listen to your information, right, and then, proper conduct is taken [...]. (N3)

I guess I would improve the participation of the nurse in bedside round, specifically speaking of the ICU, [...] sometimes he can't even participate in bedside round and usually when he participates, he is a mere spectator, he's not given the word, nor he manifests himself spontaneously. (D2)

There is a visible intimate relationship between power and knowledge, between visibility and knowledge. While being a participant and active in any process brings visibility, it also brings a higher level of responsibility and exposure of this professional, in a cycle in which knowledge encourages the subject to show him/herself, and there is no need to allow space for a manifest ${ }^{(24)}$. 


\section{DISCUSSION}

Foucault regards power as something that operates through discourse. Through discourse, what is known is said ${ }^{(8)}$, and knowledge occurs according to power relations in which knowledge generates power in the person who legitimizes it through the discourse of truth ${ }^{(19)}$. The constitution of subjectivity occurs in relationships established between individuals and the identity is constituted through the position occupied by the subject in the discourse. According to his social position, the individual's opinion is valued more or less. You become a subject when you attach to an identity and, depending on that identity, the position you occupy can be very restrictive and limited, thereby influencing your choices and practices ${ }^{(8)}$.

Subjectivity is legitimate and shaped in gestures, posture, discourses and the look ${ }^{(25)}$. While some nurses expressed hesitation in talking about themselves as professionals, physicians easily defined their conception of professional identity and used an objective and direct discourse.

Although in their discourse, physicians mentioned care as the essence of the profession, the process of building their identity gives high priority to technical actions ${ }^{(26)}$. It was also perceived that care performance as the essence of nurses' work produces negative effects, compared to the visibility provided to these professionals by service management ${ }^{(15)}$. Visibility is closely related to power and its manifestations, but the power relationship should not be confused with violence. The power relationship is established only when the two subjects are free to resist domination, and there is a power relationship only in the presence of freedom ${ }^{(3)}$. The power relationship must be understood as a fluctuating relationship therefore, it is not in an institution or a person. Knowledge, in turn, is in a relation of shapes and content. Although the establishment of power requires strength, the establishment of knowledge is enough to learn or teach about the hidden object and, in this circularity caused by the intersection of one and the other, power and knowledge, the subject is constituted ${ }^{(20,22)}$.

Nursing is in interaction with other health professions and has a characteristic identity regarding its knowledge, history, and its process of social and cultural construction in the field of care to the health of people, groups and society ${ }^{(27)}$. Care is the essence of Nursing and requires specific training and scientific knowledge for the foundation of nurses' work. However, the time allocated to this care in its complexity has been somewhat limited given the demands of care, managerial and administrative activities ${ }^{(28)}$, which leads to a difficulty in recognizing the own identity of Nursing.

Although the medical and nursing teams should work together on behalf of patients, doctors do not seem to understand the role and scope of nurses' practice. They attribute responsibilities to nurses that are not part of these professionals'scope, which leads to a certain distance between them ${ }^{(29)}$. The purpose of nursing care is primarily the relief of human suffering by providing means to manage crises, and life and death experiences ${ }^{(13)}$. However, this care practice has not always favored the establishment of nursing as an autonomous profession in the performance of care. Its devaluation is part of a process of alienation and loss of autonomy, because care is the essence of nurses' professional practice. In this study, we perceived the need to move away from this practice in the search for recognition.
In this study, the bedside round emerged as the possibility of a new place for nurses within the care team. Such an activity highlights the intimate relationship between power and knowledge, between visibility and knowledge. It can be understood as a meeting of various types of professional knowledge that gain visibility before the team and even before patients and can guarantee a position of power to professionals who have their speech truly recognized. Thus, emerges a possibility of circulation of power ${ }^{(3)}$ and its seizure by several professionals, including nurses.

Although physicians have a clearer understanding of interprofessional collaboration in the routine of health practices, nurses have a more positive attitude towards this collaboration in the intensive care setting ${ }^{(30)}$, since historically physicians have always been in a position of higher power ${ }^{(31)}$. The fact that physicians participating in this study, as a rule, choose to discuss cases and define conduct only among their peers may reflect nurses identity impasse linked to the power delegated to physicians by nursing itself.

From the medical perspective, its hierarchical differentiation is necessary and fundamental, since individuals studies more to become a physician than to become a nurse ${ }^{(32)}$. However, the alleged differences in knowledge do not necessarily result from the amount of hours invested in the training of each professional, because scientific knowledge alone is not sufficient to provide clinical practitioners with clinical competence or satisfactory medical performance ${ }^{(12,15)}$.

The mechanics of power defined by Foucault is the domain over the others' bodies not only to make them do what one wants, but in order that they operate in a way that one is pleased. Therefore, discipline makes submissive bodies, the so-called docile bodies. The body of physicians and nurses can be perceived as a multisegment machine that, in the juxtaposition process, occupies different places in the same environment, acts as combined pieces in which some must adjust to the time of others in order to extract the maximum amount of forces of each individual and combine them into an excellent result ${ }^{(3)}$.

In this sense, nurses seek the position of power by taking over the role of guardian of institutional norms, of inspector, including norms applied to the work of physicians. For Foucault, those with the role of inspecting and monitoring work processes usually have an air of superiority and command, sometimes necessary when monitoring a crowd ${ }^{(3)}$. When nurses take over this activity as an additional role to their care demands, they become the embodiment of this coercive figure.

According to studies, although nurses are available for teamwork, they still consider that physicians have the power of decision making in the therapy ${ }^{(26,33)}$. Corroborating with the present study findings, other studies indicate that the quality of care provided is directly proportional to the quality of the relationship between health professionals. In spite of the challenge of working together, physicians and nurses must find ways to be partners for meeting critical patients' care needs with primacy ${ }^{(16,26,29,31,34)}$.

\section{Study limitations}

The main limitation of this study was the restriction to the analysis of relationships established in the context of physicians 
and nurses of the Intensive Care Unit. Further studies should be conducted in different units of a hospital structure for an understanding of the size and scope of the effects of power relations in scenarios involving different practices and requiring different knowledge of these professionals.

\section{Contributions to the area of nursing, health or public policy}

The aim of this study was to elucidate how health practices between physicians and nurses are configured based on the power relations taking place in a specific environment. The results of the study draw attention to the strategies of 'time of resistance' and 'time of submission' to the disciplinary power in the team context, and emphasize the close relationship between power and knowledge, with repercussions on the recognition of the professional before the team. However, by assuming the possibility of circulation of power, we understand that positions can be questioned and modified, with consequent modification of care practices. Thus, studies of this nature can support reflections on individual and collective attitudes and practices in the perspective of establishing greater fluidity in the relationship between physicians and nurses in favor of an increasingly qualified and safe care.

\section{FINAL CONSIDERATIONS}

Through the discourses of physicians and nurses from an ICU, we sought to develop a critical understanding of how power relations influence their performance. Considering the unrestricted presence of these relationships in all human coexistences, certainly there was no intention to end the discussion about the configuration of health practices from the perspective of power relations in the ICU, but to identify some nuances expressively presented in the delineation of the work structure and in the configuration of team relationships.

The results indicated that identity, discipline and circulation of power are interdependent elements connected in a continuous movement of subjectivation of the subject that in turn, uses discourse as a persuasion strategy to modify the position taken over in different situations, causing the circulation of power. However, the close relation between power and knowledge must be acknowledged, as well as the fact that legitimate knowledge produces power.

We believe this work may foster new discussions about power in the constitution of health practices, which may contribute to a better understanding of these activities from the perspective of the work of physicians and nurses working in intensive care units.

\section{REFERENCES}

1. Mendes EV. Organização Pan-americana de Saúde. As redes de atenção a saúde [Internet]. 2. ed. Brasília: Organização Pan-americana de Saúde 2011 [cited 2016 May 16]. 549 p. Available from: http://apsredes.org/site2012/wp-content/uploads/2012/03/Redes-de-Atencao-mendes2.pdf

2. Ferreira LCM, Garcia FC, Vieira A. Relações de poder e decisão: conflitos entre médicos e administradores hospitalares. Rev Adm Mackenzie 2010;6(11):31-54. doi: 10.1590/S1678-69712010000600004.

3. Foucault M. Vigiar e Punir: Nascimento da prisão. 42. ed. Petrópolis 2014. 302 p.

4. Vendemiatti M, Siqueira ES, Filardi F, Binotto E, Simioni FJ. Conflito na gestão hospitalar: o papel da liderança. Ciênc Saúde Coletiva [Internet]. 2010[cited 2016 May 16];1(15):1301-14. Available from: http://www.scielo.br/pdf/csc/v15s1/039.pdf

5. Oliveira AM, Lemes AM, Machado CR, Silva FL, Miranda FS. Relação entre enfermeiros e médicos em hospital escola: a perspectiva dos médicos. Rev. Bras. Saúde Matern. Infant [Internet]. 2010[cited 2016 May 16];10(2):433-9. Available from: http://www.scielo.br/pdf/rbsmi/ v10s2/23.pdf

6. Riaz A, Haider MH. Role of transformational and transactional leadership on job satisfaction and career satisfaction. Beh Business Econ Horizons [Internet]. 2010[cited 2016 May 16];1(1):29-38. Available from: http://www.academicpublishingplatforms.com/downloads/pdfs/ beh/volume1/201103201428_05_V1_PAKISTAN_BEH_Adnan_Riaz_d.pdf

7. Oliveira BRG, Collet N. Relações de poderes (inter)profissionais e (inter)institucionais no hospital. Rev Bras Enferm [Internet]. 2000 [cited 2016 May 16];2(53):295-300. Available from: http://www.scielo.br/pdf/reben/v53n2/v53n2a15.pdf

8. Foucault M. Arqueologia do Saber. São Paulo: E. Edições 70, 2016.

9. Velloso ISC, Ceci C, Alves M. Reflexões sobre relações de poder na prática de enfermagem. Rev Gaúcha Enferm [Internet]. 2010 [cited 2016 May 16];31(2):388-91. Available from: http://dx.doi.org/10.1590/S1983-14472010000200026

10. Minayo MCS. Sampling and saturation in qualitative research: consensuses and controversies. Rev Pesqui Qualit [Internet]. 2017 [cited 2016 May 16];7(5):1-12. Available from: https://editora.sepq.org.br/index.php/rpq/article/view/82

11. Erasga DS. Methodological promises of discourse analysis in Philippine environmental research. Pacific Asia Inquiry 2012;3(1):116-131.

12. Jorge Neto AD. Identidade Profissional e as Humanidades na Famed/UFU. Rev Bras Educ Médica [Internet] 2013[cited 2016 May 16];2(37):266-74. Available from: http://www.scielo.br/pdf/rbem/v37n2/15.pdf

13. Pimenta AL, Souza ML. The professional identity of nursing in the papers published by Reben. Texto Contexto Enferm. 2017;26(1):1-9. doi: 10.1590/0104-07072016004370015

14. Wermuth MAD, Santos ALC. Michel Foucault e a Arquealogia/genealogia do poder: da sociedade disciplinar à biopolítica. Rev Quaestio luris [Internet]. 2016[cited 2016 May 16];1(9):405-24. doi: 10.12957/rqi.2016.17727 
15. Santos PS, Bernardes A, Vasconcelos RMA, Santos RS. Relação entre médicos e enfermeiros do hospital regional de Cáceres Dr. Antônio Fontes: a perspectiva do enfermeiro. Rev Ciênc Est Acad Med [Internet]. 2015[cited 2016 May 16];4:10-28. Available from: https://periodicos. unemat.br/index.php/revistamedicina/article/view/911

16. Paradis E, Leslie M, Puntillo K, Gropper M, Aboumatar HJ, Kitto S, et al. Delivering interprofessional care in intensive care: a scoping review of ethnographic studies. Am J Crit Care. 2014;23(3):230-8. doi: 10.4037/ajcc2014155

17. Hughes B, Fitzpatrick JJ. Nurse-physician collaboration in an acute care community hospital. J Interprof Care. 2010;24(6):625-32. doi: $10.3109 / 13561820903550804$

18. Pena RCA, Pena MLA. “O saber socrático e platônico”. Contribs Cienc Soc[Internet]. 2013[cited 2016 May 16]. Available from: http://www. eumed.net/rev/cccss/26/socrates-platon.html

19. Bordin TM. O saber e o poder: a contribuição de Michel Foucault. Saberes[Internet]. 2014[cited 2016 May 16];1(10):225-35. Available from: https://periodicos.ufrn.br/saberes/article/view/5088

20. Velloso I, Ceci C, Alves M. Configurations of power relations in the Brazilian emergency care system: analyzing a context of visible practices. Nurs Inquiry. 2013;20(3):256-64. doi: 10.1111/j.1440-1800.2012.00602.x

21. Velloso ISC, Araújo MT, Nogueira JD, Alves M. Mobile Emergency Care Service: the work on display. Texto Contexto Enferm. 2014 23(3):538546. doi: 10.1590/0104-07072014000030013

22. Ferreirinha IMN, Raitz TR. As relações de poder em Michel Foucault: reflexões teóricas. Rev Adm Pública. 2010;44 (2):367-83. doi: 10.1590/ S0034-76122010000200008

23. Houaiss A, Villar MS. Dicionário Houaiss da língua portuguesa. Rio de Janeiro: Objetiva; 2009. 1986 p.

24. Foucault M. O governo de si e dos outros. 2 ed. São Paulo: E. WMF Martins Fontes, 2017. 400p.

25. Fischer RMB. Foucault e o desejável conhecimento do sujeito. Educação e realidade 1999;24(1):39-59.

26. Tang CJ, Chan SW, Zhou WT, Liaw SY. Collaboration between hospital physicians and nurses: An integrated literature review. Int Nurs Review. 2013;60(3):291-302. doi: 10.1111/inr.12034

27. Bellguarda MLR, Silveira LR, Mesquita MPL, Ramos FRS. Identidade da profissional enfermeira caracterizada numa revisão integrativa. Enferm Foco [Internet]. 2011 [cited 2016 May 16];3(2):180-3. Available from: http://revista.portalcofen.gov.br/index.php/enfermagem/ article/viewFile/130/111

28. Santos AG, Monteiro CFS, Nunes BMVT, Benício CDAV, Nogueira LT. O cuidado em enfermagem analisado segundo a essência do cuidado de Martin Heidegger. Rev Cubana Enferm [Internet]. 2017 [cited 2016 May 16];33(3):[aprox.0p.]. Available from: http://www.revenfermeria.sld. cu/index.php/enf/article/view/1529

29. Lancaster G, Kolakowsky-Hayner S, Kovacich J, Greer-Williams N. Interdisciplinary Communication and Collaboration Among Physicians, Nurses, and Unlicensed Assistive Personnel. J Nurs Scholarship. 2015 Mar;47(3):275-284. doi: 10.1111/jnu.12130

30. Sollami A, Caricati L, Sarli L. Nurse-physician collaboration: a meta-analytical investigation of survey scores. J Interprof Care. 2014;3(29):2239. doi: 10.3109/13561820.2014.955912

31. Vegesna A, Coschignano C, Hegarty SE, Karagiannis T, Polenzani L, Messina E, et al. Attitudes towards physician-nurse collaboration in a primary care team-based setting: survey-based research conducted in the chronic care units of the Tuscany region of Italy. J Interprof Care. 2016 Jan;30(1):65-70. doi: 10.3109/13561820.2015.1081878

32. Bazzarelli IM, Amorim MCS. Gênero, representação simbólica e origem social nos conflitos entre médicos e enfermeiras. Rev Psicol Polít. 2010;19(10):75-89. Available from: http://pepsic.bvsalud.org/scielo.php?script=sci_arttext\&pid=S1519549X2010000100007\&lng=pt\&nrm=iso

33. Nair DM, Fitzpatrick JJ, McNulty R, Click ER, Glembocki MM. Frequency of nurse-physician collaborative behaviors in an acute care hospital. J Interprof Care. 2011;2(26):115-20. doi: 10.3109/13561820.2011.637647

34. Boev C, Xia Y. Nurse-Physician collaboration and hospital-acquired infections in critical care. Crit Care Nurse. 2015;35(2):66-72. doi: 10.4037/ ccn2015809 